\title{
Numerical modeling of the development of southeastern Red Sea continental margin*
}

\author{
Sunil Kumar Dwivedi ${ }^{*}$ and Daigoro Hayashi \\ Simulation Tectonics Laboratory, Faculty of Science, University of the Ryukyus, Okinawa 903-0213, Japan
}

\begin{abstract}
The Red Sea continental margin (RSCM) corresponds to a wide hinge zone between Red Sea and Arabian plate. This margin has been studied through geological and geophysical observations primarily in regard to the evolution of Red Sea rift. This margin is characterized by occurrence of thin sediments, significant onshore uplift, tectonic subsidence of the offshore sedimentary basin, active faulting and seismicity. Studies indicate that sedimentary sequences of the margin are deformed by faults and folds resulting from at least two phases of extension and a phase of uplift. During the two phases of extension due to regional plate stress the sequence was cut by set of extensional faults. While during the phase of uplift the sequence was deformed by folding and faulting. The present paper aims to clear the structural development of RSCM during these tectonic episodes, taken as particular tectonic event, by two-dimensional finite element modeling on plane strain condition. Elastic rheology is assumed for the oceanic, continental and transitional crust along with syntectonic deposits. Stress field, shear stress and fault distribution suggests that mantle plume weakened the crust following rifting due to regional stress and developed the margin. These results are well consistent with those from present seismicity, active faulting and neotectonic studies.
\end{abstract}

Key words: Red Sea rift; continental margin; numerical modeling; seismicity; neotectonics CLC number: P542 Document code: A

\section{Introduction}

Continental rift and its margin, which are formed by the extension of the lithosphere (Bott, 1976; McKenzie, 1978), offers an excellent opportunity to understand breakup processes during extension. Regional stress field or thermal upwelling of the asthenosphere, inherited zones of weakness and the rheological structure of the lithosphere are the factors contributing to the initiation of rifting and deformation of lithosphere (Sengör and Burke, 1978; Turcotte and Emermen, 1983; Voggenreiter et al, 1988; Ziegler and Cloetingh, 2004). The Red Sea rift, which extends from Gulf of Aden and Afar triple junction in the south into Gulf of Suez and Dead Sea transform in the north, is a spectacular example of lithospheric extension (Figure 1). It is marked by its distinct morphology, seismicity and neotectonic deformation. Plate kinematic studies and earthquake fault plane solutions show that the tectonic regime of the African-Arabian plate boundary in the Red Sea is changing

\footnotetext{
* Received 21 November 2008; accepted in revised form 13 March 2009; published 10 June 2009.

• Corresponding author. e-mail: sunildwd@gmail.com
}

progressively from continental rifting to seafloor spreading (Bonatti, 1985; Girdler and Underwood, 1985; Chu and Gordon, 1998; Dwivedi and Hayashi, 2008).

Like other passive continental margins Red Sea continental margin (RSCM) has drawn considerable interest due to its potential as major hydrocarbon reservoirs (Alsharhan and Salah, 1995; Alsharhan and Nairn, 1997; Konert et al, 2001). High thermal gradients along the margin form an area for good hydrocarbon potential. RSCM is characterized by occurrences of thin sediments with significant onshore uplift and tectonic subsidence as well as the zone of high seismicity and active faults related to extending lithosphere (Bohannon, 1986; Giraud et al, 1986; Hempton, 1987; Pallister, 1987; Voggenreiter et al, 1988; Bohannon et al, 1989; Davison et al, 1994; Johnson, 1998; Dwivedi and Hayashi, 2006, 2007). Several generations of active faults, block faulting and listric normal faults created by the volcanic eruptions strongly suggests regional uplift and tilting (Pallister, 1987; Davison et al, 1994; Kaliwoda et al, 2007). Off-axis volcanism has been one of the principal lines of evidence for simple shear models of continental rifting (Wernicke, 1985; Bosworth, 1987; Voggenreiter et al, 1988). 


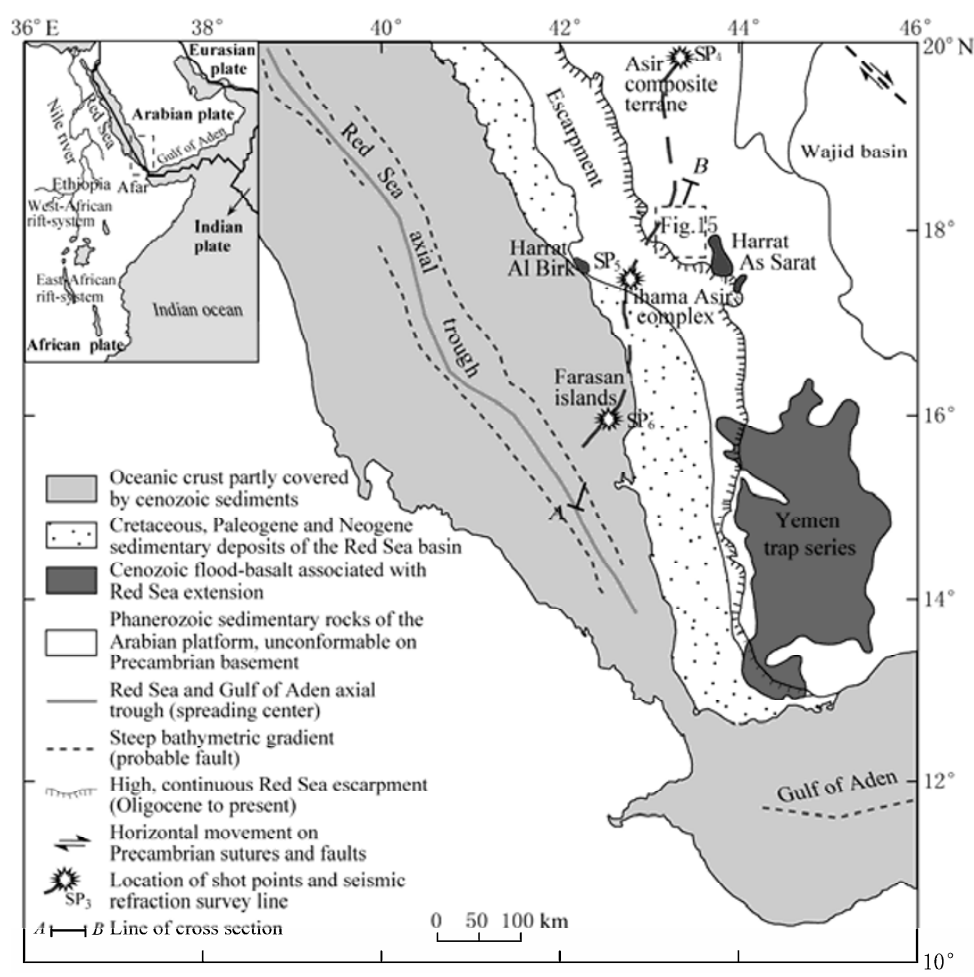

Figure 1 Location and geology of Red Sea and its margin (modified after Johnson, 1998). Overview map is shown in the inset.

Previous studies on the RSCM mainly focus on its tectonic evolution by geological and geophysical observations and much of its development either by the regional plate stress or mantle plume has been a debatable issue (Mooney et al, 1985; Bohannon, 1986; Hempton, 1987; Pallister, 1987; Voggenreiter et al, 1988; Bohannon and Eittreim, 1991; Makris and Rhim, 1991; Davison et al, 1994). As noted by various authors, an evolution of RSCM has been episodic with prolonged hiatus around 14-5 Ma BP followed by faster extension (Girdler, 1985; Hempton, 1987, Voggenreiter et al, 1988) (Figure 2). The first stage of extension is commonly dated at the Oligocene, around $28 \mathrm{Ma}$ BP. Consequently, uplift of the lithosphere occurred around 18 Ma BP due to the deactivation of continental shear zone pursued by gabbroic magmas (or Tihama Asir magmatic complex). The second stage of extension (sea-floor spreading) started at around $5 \mathrm{Ma} \mathrm{BP}$ and probably confined to the central axis of the Red Sea where thermal weakening has localized the deformation. Present-day seismicity supported by historical events, however, indicates that medium magnitude earthquake swarms are common in the margin and onshore deformation is still continuing (Merghelani and Gallanthine, 1980; Am- braseys and Melville, 1983; Bohannon, 1986; Pedone et al, 1992; Al-Amri, 1994). In this study, following the model of Voggenreiter et al (1988) and using our finite element modeling, the debatable issue of the development of RSCM will be further clarified. The relative magnitude and pattern of the tectonic stresses, shear stress, and fault development will be modelled with varying rock parameters on various tectonic boundary conditions.

\section{Geological setting}

The Red Sea rift basin originated from an Oligocene continental rift impacted by left-lateral wrenching. Oligocene continental rifting began with extension, subsidence, normal faulting and sedimentation associated with episodic and segmented movement of Arabian peninsula away from Africa. Magmatic expansion resulted in igneous emplacements, and isostatic rebound caused the rift to undergo uplift and local erosion into the rapidly subsiding and tilting basins (Pallister, 1987; Bohannon et al, 1989; Kaliwoda et al, 2007). At depth, RSCM is underlain by a thick Cenozoic sedimentary wedge over oceanic-continental transitional zone. The sedimentary sequences are deformed by faults and folds 

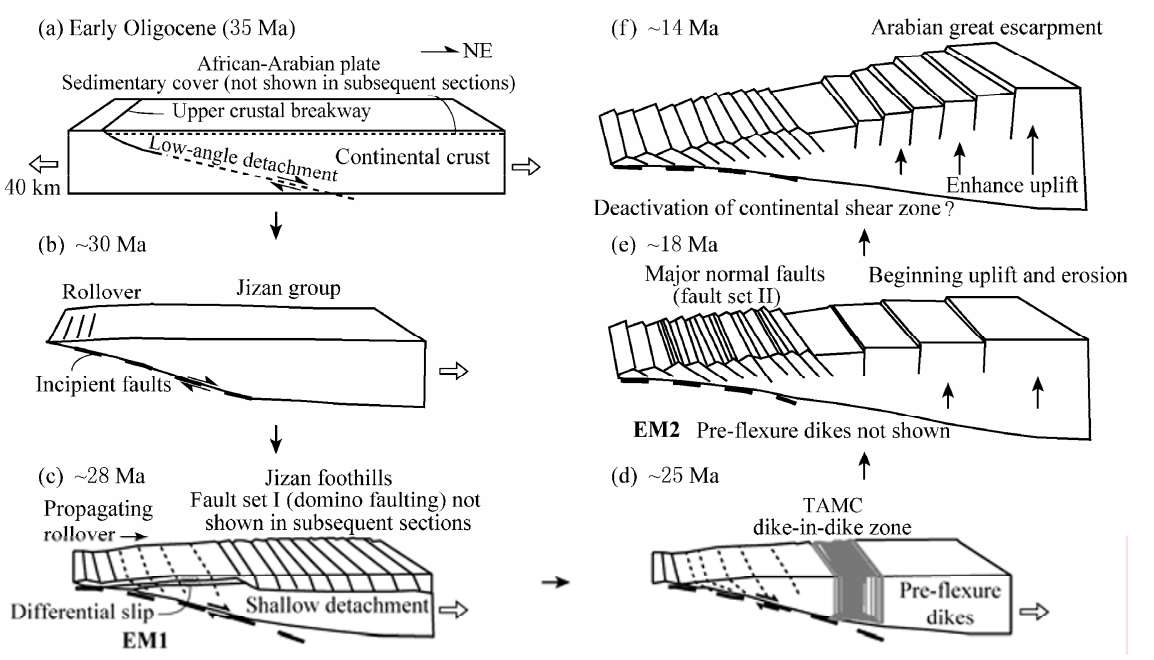

Figure 2 Schematic model showing the development of RSCM (after Voggenreiter et al, 1988).

resulting from at least two phases of extension and a phase of uplift (Figure 2) (Voggenreiter et al, 1988). During the two phases of extension, due to regional plate stress, the sequence was cut by a set of extensional faults. While during the phase of uplift the sequence was deformed by folding and faulting.

The landscape of the RSCM is spectacular, which is divided into several regions on the basis of topography and structure (Johnson, 1998) (Figure 1). The Tihama plain, which is about $40 \mathrm{~km}$ wide coastal plain trending $\mathrm{N}-\mathrm{S}$, rises gently from the Red Sea shores to an altitude of $\sim 200 \mathrm{~m}$ in the east, where it is bounded by the great escarpment or Asir mountains. The most striking feature of the margin is this great escarpment, which trends in NW-SE direction and can be traced from southern Yemen northward for more than $1000 \mathrm{~km}$ into Saudi Arabia This escarpment consists mainly of granitic and metamorphic rocks, rises abruptly from an altitude of $\sim 200 \mathrm{~m}$ to $>2000 \mathrm{~m}$ above the sea level and suggests regional uplift and tilting. The area has been dominated by basic dike swarm with several generations of normal faults suggesting overall NE-SW extension. Davison et al (1994) divided the southeastern Red Sea passive margin into following: (1) Cenozoic Red Sea basin, which consists the Red Sea and coastal plain that contain synrift sediments and sedimentary rocks; (2) Oceanic crust below the Red Sea basin; (3) Continental crust in the Arabian shield mostly composed of Precambrian rocks; (4) Small basins inland RSCM contain Cenozoic sedimentary rocks that reflect local extensions; (5) Large fields of Cenozoic dikes and of Cenozoic to Recent basalt (Harrats) that extruded unconformably on the shield and on sedimentary rocks of the Red Sea basin. Most of these parts can be observed on the interpreted seismic section of Mooney et al (1985) (Figure 3). The Cenozoic synrift and post-rift geological succession of the RSCM in Tihama Asir is summarized in Table 1. The geological succession provides important information to understand the late phase of continental break-up, the initiation of seafloor spreading and hydrocarbon habitat along the margin (Voggenreiter et al, 1988). The Jizan group rocks are the oldest synrift deposits in the area. The basal Ayyanah formation comprises conglomerates, sandstones and limestones and covers unconformably over a Proterozoic basement. The Ad Darb formation, which consists of oldest rift-related magmatic rocks of basaltic volcanics and volcanoclastics in the Jizan coastal plain, is conformably overlain by dacitic to rhyolitic flows and ignimbrites of Liyyah formation. Volcanic tuffs are interlayered with lacustrine sediments that were deposited between the eruptive centers (Baid formation). The top of the Jizan group is made up of volcanoclastics and flows in basaltic to andesitic composition of the Damad formation. The Tihama Asir magmatic complex (TAMC), which consists of mafic dike swarm, layered gabbros and granophyres of Early Miocene age (26-18 Ma), intruded Jizan group rocks and underlying strata. Jizan group is covered by polymictic conglomerates of the Bathan formation near the Al Birk lava-field. This formation has not been intruded by TAMC rocks and therefore is probably younger than $18 \mathrm{Ma}$; it documents an enhanced uplift of the rift margin. Quaternary alkaline olivine basalts and Quaternary clastics are the youngest deposits of the margin. 


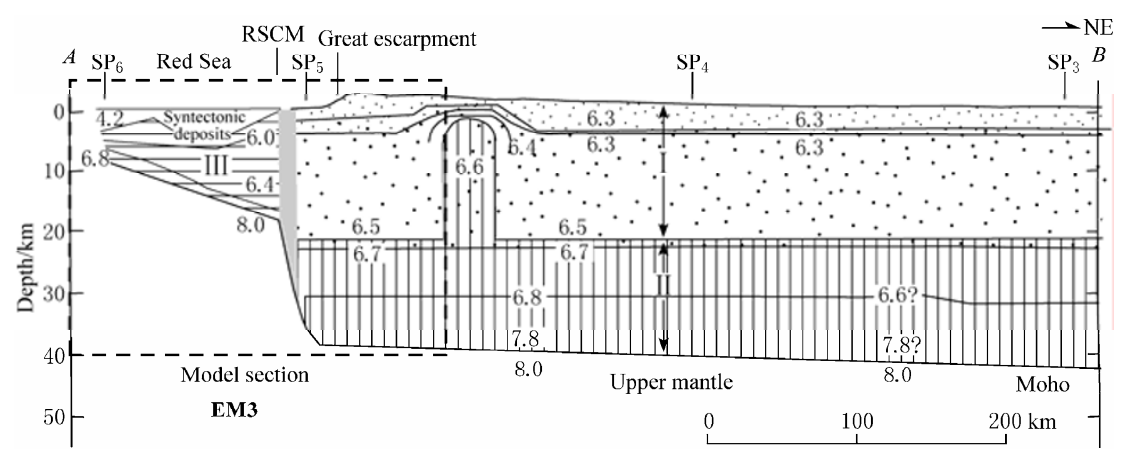

Figure 3 Crustal structure of the RSCM interpreted from seismic line data (after Mooney et al, 1985). Vertical exaggeration is 4:1. Numbers represent $\mathrm{P}$ wave velocities $\left(v_{\mathrm{P}}\right)$ in unit of $\mathrm{km} \cdot \mathrm{s}^{-1}$. SP is a seismic shot point. I, II and III denote the crustal layer 1, 2, 3, respectively.

Table 1 Cenozoic stratigraphy of the RSCM (after Schmidt et al, 1982 from Voggenreiter et al, 1988)

\begin{tabular}{|c|c|c|c|c|}
\hline \multicolumn{2}{|l|}{ Age } & \multicolumn{2}{|c|}{ Formation } & Lithology \\
\hline Quaternary & Holocene, Pleistocene & \multicolumn{2}{|c|}{ Surficial deposits and coral reefs } & Alkaline olivine basalts and clastics \\
\hline \multirow[t]{2}{*}{ Tertiary } & \multirow{2}{*}{$\begin{array}{l}\text { Pliocene, } \\
\text { Miocene and Oligocene }\end{array}$} & \multicolumn{2}{|c|}{$\begin{array}{l}\text { Raghama formation } \\
\text { Bathan formation } \\
\text { Tihama Asir magmatic complex }\end{array}$} & $\begin{array}{l}\text { - } \\
\text { Polymictic conglomerates (documents enhanced uplift of rift shoulders) } \\
\text { Mafic dike swarms, layered gabbros, and granophyres }\end{array}$ \\
\hline & & $\begin{array}{l}\text { Jizan } \\
\text { group }\end{array}$ & $\begin{array}{l}\text { Damad formation } \\
\text { Liyyah formation } \\
\text { Baid formation } \\
\text { Ad Darb formation } \\
\text { Ayyanah formation }\end{array}$ & $\begin{array}{l}\text { Volcanoclastics and basaltic to andesititc flows } \\
\text { Dacitic to rhyolitihic flows and ignimbrites } \\
\text { Volcanic ashes interlayered with lacustrine sediments } \\
\text { Basaltic volcanics and volcanoclastics } \\
\text { Conglomerates, sandstones and limestone }\end{array}$ \\
\hline
\end{tabular}

\section{Numerical modeling}

Numerical methods used to address lithospherescale deformation problems are generally based on finite element methods incorporating a variety of mechanical parameters and constitutive relationships. One popular technique is to treat the crust as elastic body, which emphasizes the elastic stresses and strains taken as the perturbation to the elastic solution. In this study, we use the two-dimensional elastic finite element (FE) package (Hayashi, 2008) under plane strain condition. This approach can be found in Hayashi (2008) and is not discussed in detail here. This FE package requires specification of an initial condition, material property and boundary condition. Therefore, to study the deformation of the RSCM, at a particular rifting event driven by far-field and basal displacements, requires local geometry and material properties. As incorporated in the FE package, failure elements are analyzed by depth-dependent yield stress using Mohr-Coulomb failure criterion (Melosh and Williams, 1989). Type of faulting is determined on the basis of Anderson's theory of faulting (Anderson, 1951).

\subsection{Model geometry and rock layer properties}

Based on the present day (0 Ma) two-dimensional vertical seismic section adopted from Mooney et al (1985) (Figure 3) and using the models of Bohannon (1986), Bohannon et al (1989), Bohannon and Eittrein (1991) and Makris and Rhim (1991), simplified model geometry for the first time of extension for $28 \mathrm{Ma}$ (EM1) and for the uplift time $18 \mathrm{Ma}$ (EM2) were constructed (Figure 4). Five brittle rock layers were identified from the seismic section for EM3. These include oceanic, continental (upper and lower), oceanic-continental transitional crust, and syntectonic deposits. On the other hand, three layers viz. continental (upper and lower) and transitional crust, were identified for EM1 and EM2. FE mesh containing 1187 triangular elements and 673 nodal points was applied for EM1 and EM2, while 1357 triangular elements and 811 nodal points was applied for EM3.

For the numerical calculations, required rock mechanical parameters such as density, Poisson's ratio, elastic modulus, cohesion and friction angle were assigned for each layer. Density $(\rho)$, cohesion $(c)$ and friction angle $(\phi)$ were taken from the average in-situ and laboratory measurements (Clark, 1966); whereas, ideal value of Poisson's ratio (v), i.e., 0.25 is taken for all layers (Figure 5). P-wave velocity $\left(v_{\mathrm{P}}\right)$ adopted from seismic 

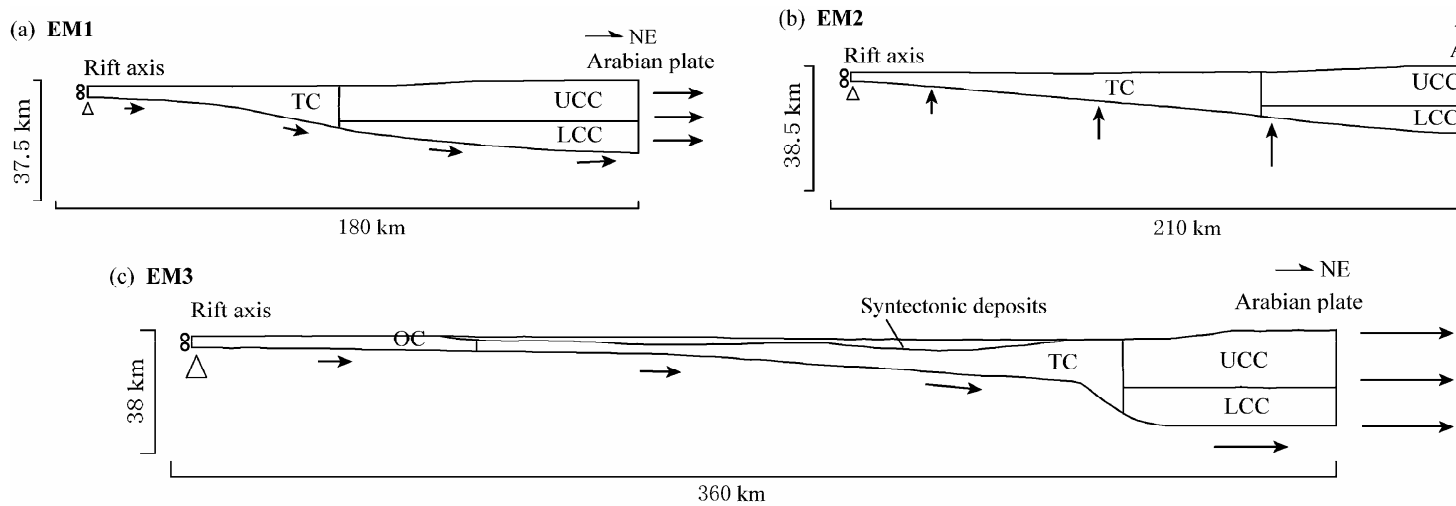

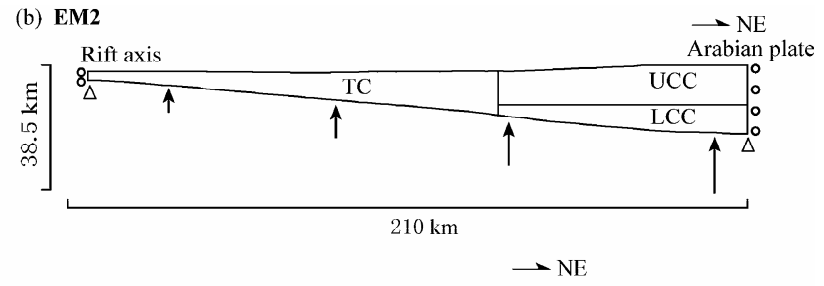

Figure 4 Model geometry and boundary conditions for EM1 (28 Ma) (a), EM2 (18 Ma) (b), and EM3 (0 Ma) (c), where UCC is upper continental crust, LCC is lower continental crust, TC is transitional crust, and OC is oceanic crust.

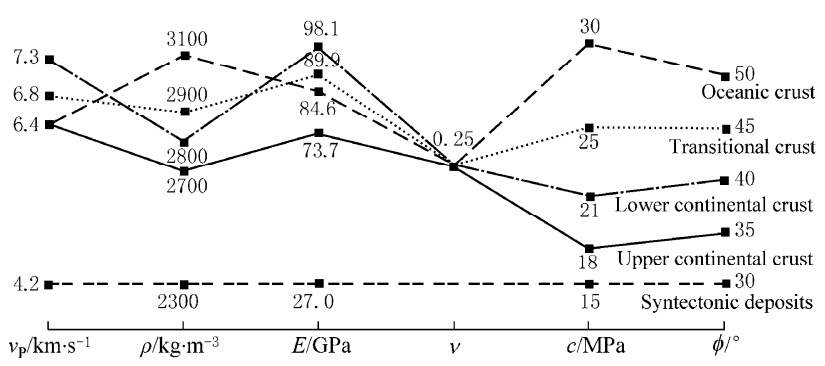

Figure 5 Rock layer property where $v_{\mathrm{P}}, \rho, E, v, c$ and $\phi$ denote P-wave velocity, density, elastic modulus, Poisson's ratio, cohesion, and friction angle, respectively.

section was then used to calculate the dynamic elastic modulus $(E)$ using equation (1) (Timosenko and Goodier, 1970). Finally, $80 \%$ of the calculated dynamic elastic, i.e., static elastic modulus, was taken for the modeling.

$$
E=\rho v_{\mathrm{P}}^{2} \frac{(1+v)(1-2 v)}{(1-v)}
$$

\subsection{Boundary conditions}

Two types of displacement boundary conditions, i.e., extension equivalent to far-field tectonic stress for EM1 and EM3, and basal displacement equivalent to uplift for EM2, were considered in our modeling (Figure 4). The upper part of model represents Earth's surface and allows free to deform in any direction. Gravitational force is taken into account assuming that the crust is mechanically isotropic. Extensional displacement $(50 \mathrm{~m}$, $100 \mathrm{~m}$ to $150 \mathrm{~m}$ ) parallel to $x$-direction is imposed progressively on right hand side of EM1 and EM3. The lower left corner is fixed, left side is free to move in $y$-direction and displacement is imposed linearly in right direction on the base of the model. On the other hand, for EM2 upward displacement ( $30 \mathrm{~m}, 60 \mathrm{~m}$ to $120 \mathrm{~m}$ ) is imposed linearly on the base of the model parallel to $y$-direction, while the left and right sides are allowed free to move in $y$-direction. For all models, the resulting stress field, failure distribution and shear stress were observed as a post process of elastic solution and are discussed.

\section{Modeling results}

Here we present the modeling results which are primarily based on: (1) distribution, orientations, and magnitude of principal stresses; (2) fault distribution (or proximity of failure elements); (3) shear stress distribution.

\subsection{State of stress}

We simulate the stress field as a function of rock layer property on displacement boundary conditions. Spatial distribution of stress field for the initial condition of the model, i.e., before any extensional or uplift events occurred, is shown in Figure 6a. On this condition compressive stresses are prevalent in all layers. The orientations of maximum compressive stress $\left(\sigma_{1}\right)$ and minimum compressive stress $\left(\sigma_{3}\right)$ are vertical and horizontal, respectively. Few tensional stresses on the upper right edge of model are found that is described as a boundary effect of the model. Similarly, stress distribution for models EM1 and EM3 at $50 \mathrm{~m}$ horizontal extensional displacement shows compressive stress in all rock layers (Figures $6 \mathrm{~b}$ and $8 \mathrm{a}$ ), where orientations of $\sigma_{1}$ and $\sigma_{3}$ are vertical and horizontal respectively. The vertical orientation of $\sigma_{1}$ in the uppermost part of the model is a typical orientation of tectonic stress during intra plate rifting. Although orientation of stress field is uniform throughout the model, magnitude of $\sigma_{1}$ and $\sigma_{3}$ seems lower in upper part than in the deeper part. This reflects the influence of gravity and crustal thickness during 
extension. With the extensional displacement increasing from $50 \mathrm{~m}$ to $100 \mathrm{~m}$ and $150 \mathrm{~m}$, tensional stress is induced significantly in the upper part of the model (Figures 6 and 8). More interestingly number of tensional stress increases and propagates downward, specially in the upper part of the crust near the Red Sea and continental margin. This is explained in terms of variation of elastic parameters, gravity and effect of crustal thickness of the model during extension. In case of EM2, under upward displacement, similar stress field is observed in the crust with orientation of $\sigma_{1}$ and $\sigma_{3}$ vertical and horizontal respectively (Figure 7 ). The magnitude of $\sigma_{1}$ and $\sigma_{3}$ in upper part of the crust is lower than that in the basement layer. With the upward displacement increasing from $30 \mathrm{~m}$ to $60 \mathrm{~m}$ and $120 \mathrm{~m}$, tensional stress is

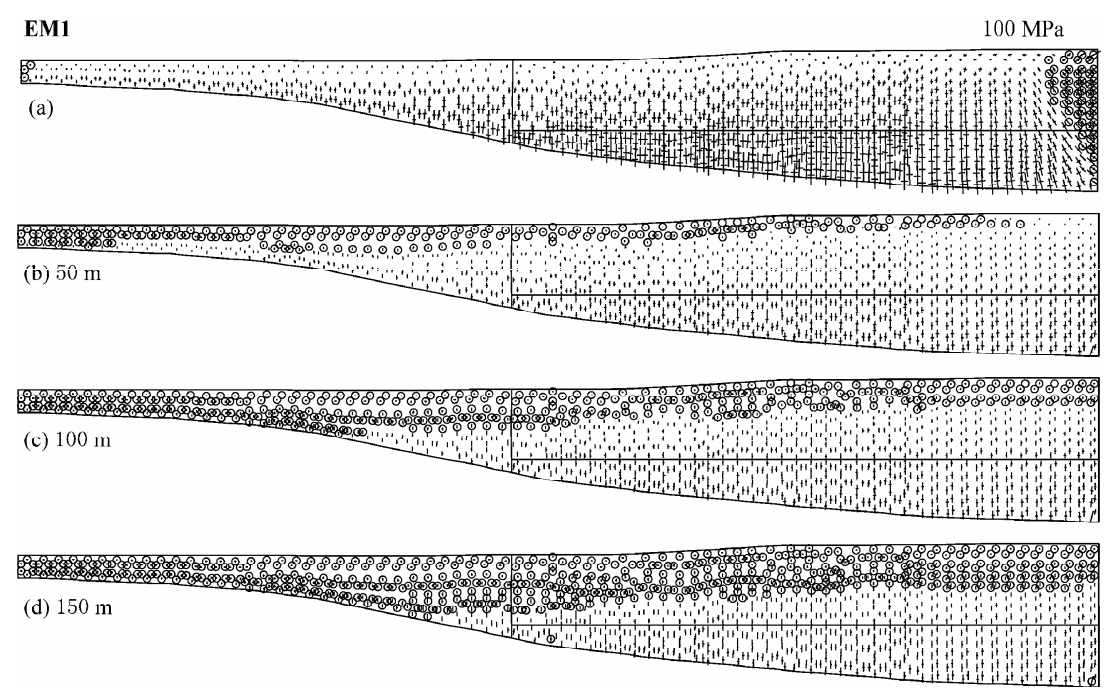

Figure 6 Stress distribution of model EM1. Each pair of perpendicular lines represent $\sigma_{1}$ (long line) and $\sigma_{3}$ (short line), small circle shows tensional stress. (a) Initial stress field; (b) Horizontal extensional displacement $d$ is $50 \mathrm{~m}$; (c) $d$ is $100 \mathrm{~m}$; (d) $d$ is $150 \mathrm{~m}$.

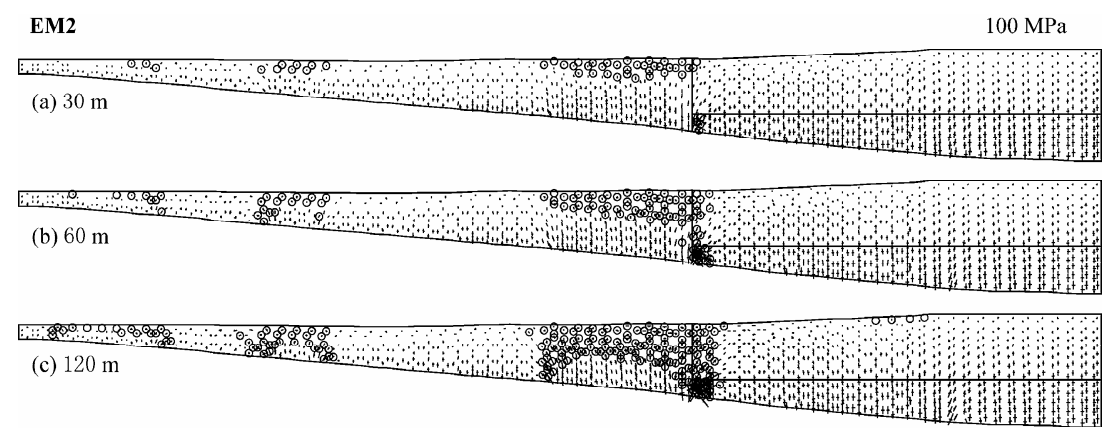

Figure 7 Stress distribution of model EM2 with upward displacement of $30 \mathrm{~m}$ (a), $60 \mathrm{~m} \mathrm{(b)}$ and $120 \mathrm{~m}$ (c). The symbols are the same as those in Figure 6.

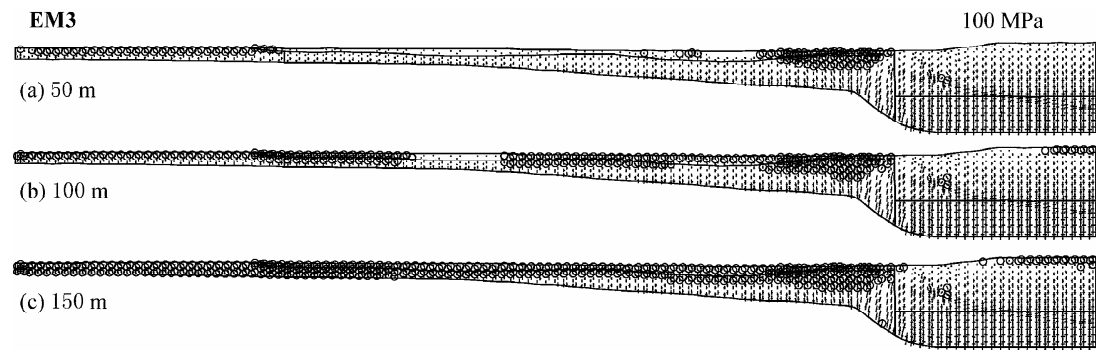

Figure 8 Stress distribution of model EM3 with horizontal extensional displacement of $50 \mathrm{~m}$ (a), $100 \mathrm{~m}$ (b) and $150 \mathrm{~m} \mathrm{(c).} \mathrm{The} \mathrm{symbols} \mathrm{are} \mathrm{the} \mathrm{same} \mathrm{as} \mathrm{those} \mathrm{in} \mathrm{Figure} 6$. 
induced in the upper part of the model (Figure 7), dominantly in the continental margin and few in the Red Sea. Perturbation of stress field can also be seen on these parts as an effect of upward displacement.

\subsection{Failure characteristics}

The failure pattern has been simulated under Mohr-Coulomb criterion, where faults are examined under proximity of failure elements. Failure pattern depends primarily on two basic rock-mechanical parameters, that is, cohesion and friction angle. These values were adopted from a series of tests in our modeling. Modeling shows seemingly different characteristics and pattern of crustal deformation under both types of boundary conditions. For EM1 and EM3 under $50 \mathrm{~m}$ extensional displacement, most of the failure elements are developed near the continental margin (Figures 9a, 11a). Also for EM1 few failure elements are observed in the Red Sea and Arabian shield. With displacement increasing from $50 \mathrm{~m}$ to $100 \mathrm{~m}$ and $150 \mathrm{~m}$, failure elements under both tension and compression are progressively developed in the upper part of the model and consequently propagate towards the deeper part (Figure 9). This is the characteristic feature of the extensional setting, where predominantly normal faults are expected in the upper crust. In case of EM2 under $30 \mathrm{~m}$ upward displacement, few faults are developed and localized in and around the continental margin (Figure 10a). When displacement increases progressively from $30 \mathrm{~m}$ to $60 \mathrm{~m}$ and $120 \mathrm{~m}$, failure elements are progressively developed on the shallow part of the model, most significantly near and below the continental margin (Figure 10). Comparing with EM1 and EM3, EM2 shows failure elements that are deeply rooted below the margin. This eventually shows the effect of basal displacement on the origin of extensional features in the RSCM.

\subsection{Shear stress distribution}

Distributions of shear stress on both boundary conditions are calculated for the three models. High shear stress region permits rupture along pre-defined fault zones where the possibility of deformation is high. Calculated shear stress for EM1 and EM3 shows uniform distribution throughout the model (Figures 12a and c). Low shear stress value ( $20 \mathrm{MPa})$ occurs in the upper part of the model, whose magnitude increases gradually towards the deeper part reaching about $160 \mathrm{MPa}$ near

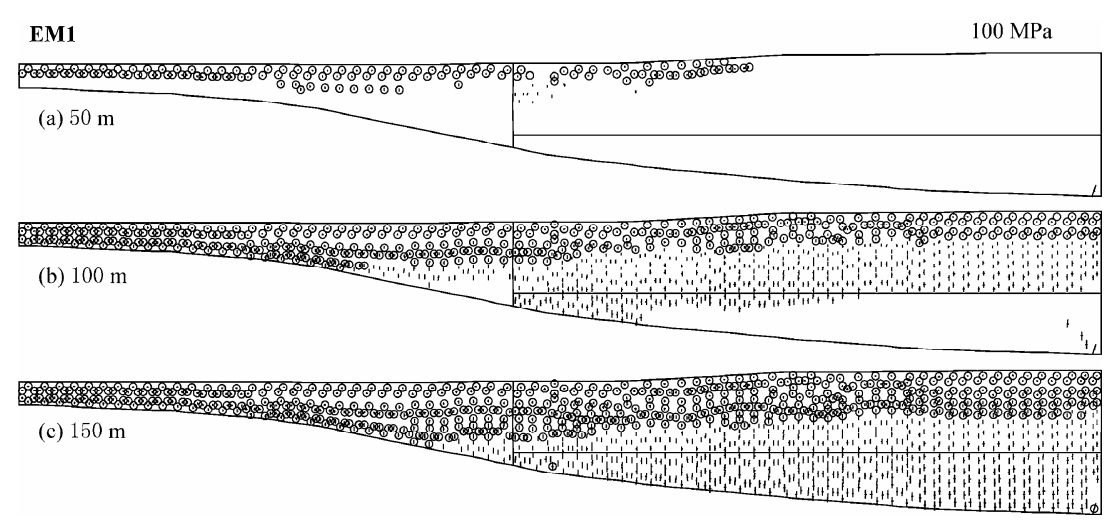

Figure 9 Stress distribution within failure elements of model EM1 with horizontal extensional displacement of $50 \mathrm{~m}$ (a), $100 \mathrm{~m}$ (b) and $150 \mathrm{~m}$ (c). The symbols are the same as those in Figure 6.

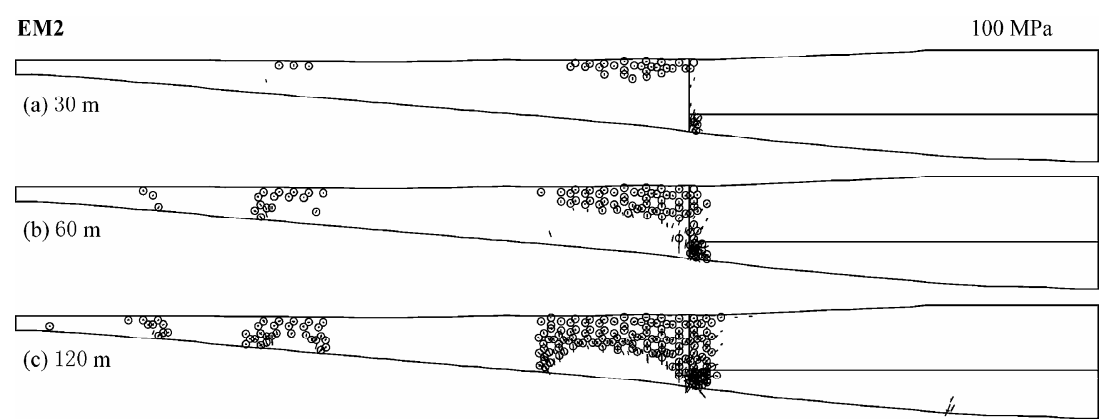

Figure 10 Stress distribution within failure elements of model EM2 with upward displacement of $30 \mathrm{~m}$ (a), $60 \mathrm{~m}$ (b) and $120 \mathrm{~m}$ (c). The symbols are the same as those in Figure 6. 


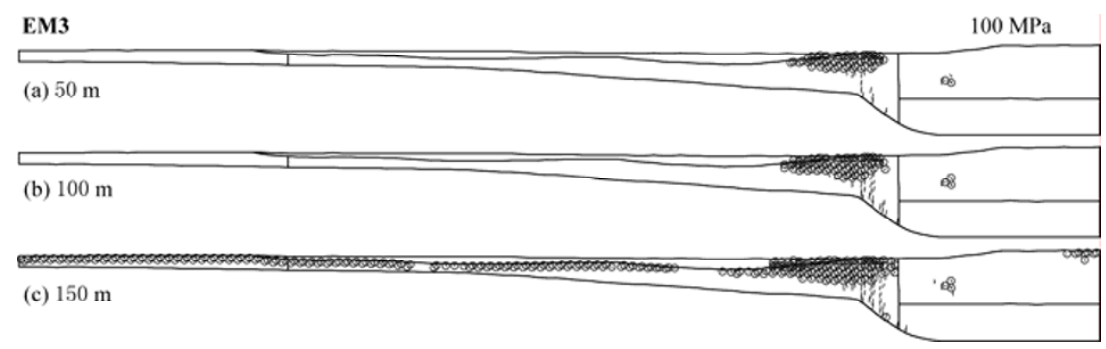

Figure 11 Stress distribution within failure elements of model EM3 with horizontal extensional displacement being $50 \mathrm{~m}$ (a), $100 \mathrm{~m}$ (b) and $150 \mathrm{~m}$ (c). The symbols are the same as those in Figure 6.
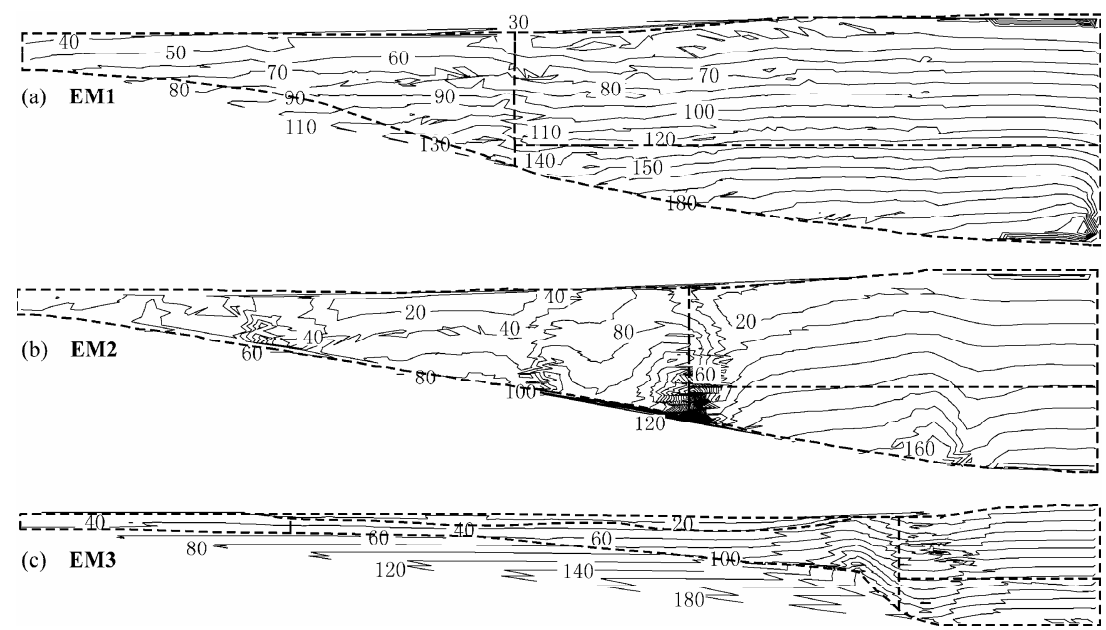

Figure 12 Contour map of maximum shear stress (unit in MPa). (a) For model EM1 with $100 \mathrm{~m}$ horizontal extensional displacement; (b) For model EM2 with 60 m upward displacement; (c) For model EM3 with 100 m horizontal extensional displacement.

the base of the continental crust and $180 \mathrm{MPa}$ exactly below the RSCM. In the case of EM2, where shear stresses are not uniformly distributed throughout the model (Figure 12b), similar pattern of shear stress is shown with magnitude about $180 \mathrm{MPa}$ below the RSCM, which clearly indicates high strain to be prevalent along the RSCM during phases of extension and uplift. This could be one of the main reasons for active tectonics and deformation along the margin.

\section{Discussion}

\subsection{Source of active deformation}

The state of stress in the Red Sea has been dominantly controlled by regional far-field stress, uplift, volcanism and seafloor spreading during its evolution. Studies have shown that the horizontal extension direction in the Red Sea is changing following the changing direction of African-Arabian plate (Bosworth and Strecker, 1997; Guiraud and Bosworth, 1997, 1999; Dwivedi and Hayashi, 2008). Active faulting and neotectonic studies have indicated that the general Quaternary extension was dominantly in NE-SW direction, which is equivalent to the present-day stress field (Giraud et al, 1986; Strecker et al, 1990; Strecker and Bosworth, 1991; Al-Amri, 1994; Bosworth and Strecker, 1997) (Figure 13). Although the source of extensional stresses in the Red Sea is under the speculation, it is widely accepted that it is derived from Arabian-Eurasian plate convergence in Iran, and westward extrusion of Anatolia in Turkey provided by left-lateral slip along the Dead Sea transform (Hempton, 1987; Reches and Schubert, 1987; Girdler, 1991; Ambraseys et al, 1994; Ghebreab, 1998). This is also supported by more recent geodetic observations (Reilinger et al, 1997; McClusky et al, 2003), kinematic models (Joffe and Garfunkel, 1987; Chu and Gordan, 1998) and neotectonic studies (Bohannon, 1986; Vita-Finzi, 2001). On the other hand, it is recognized that volcanism and sea-floor spreading is occurring in the Red Sea due to upwelling of mantle plume from mantle convection currents (Bonatti and Seyler, 1987; Pallister, 1987; White and McKenzie, 1989). 


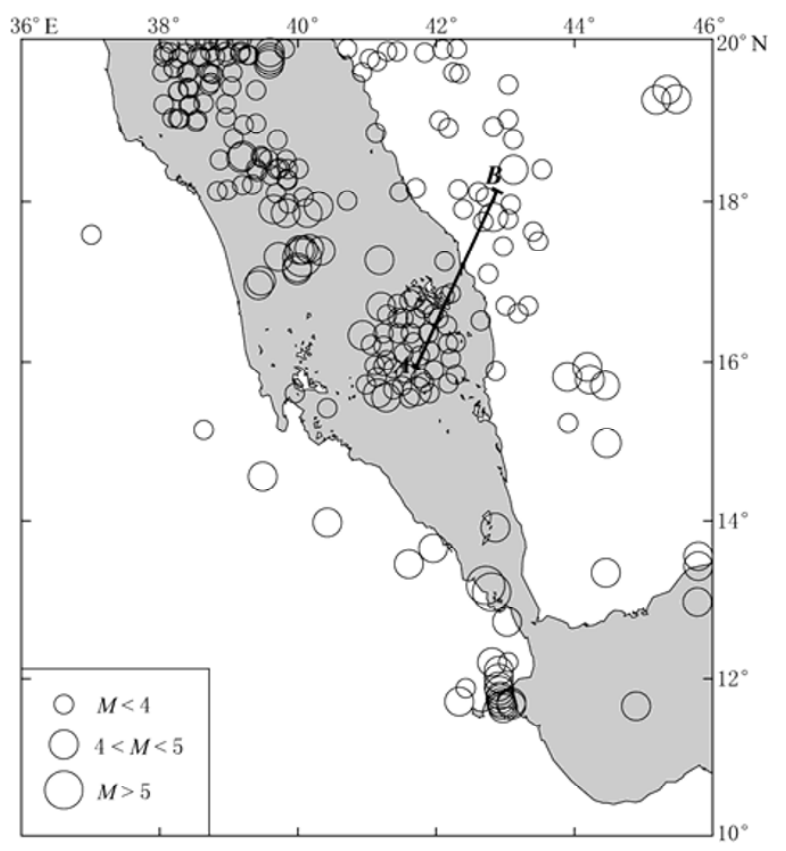

Figure 13 Seismicity map of the studied area (compiled from Al-Amri, 1994 and http://discoverourearth.org/webmap/). $A B$ is a line of cross section.

\subsection{Neotectonics, active faulting and seismicity}

Seismicity and active faulting studies show that southeastern part of Red Sea rift segment is tectonically active and evidenced by numerous dikes, shear zones, fractures, normal faults and magnetic trends (Figure 14). This area is an efficient avenue for the hydrocarbon deposits and mineral resources. In fact, the migration and flow of hydrocarbon are genetically related to and controlled by the tectonic stress, rock fabrics, and process of faulting (Finkbeiner et al, 2001). Geomorphological and structural observations from recent Quaternary faults of Wajid sandstone (Figure 15), Farasan islands, and Wadis areas as well as raised coral terraces suggest several active faults and uplifting blocks diverted major rivers and produced highlands along the RSCM (Merghelani and Gallanthine, 1980; Barazangi, 1981; Bohannon, 1986; Bohannon et al, 1989). Surface expressions of faults and folding over the sedimentary sequences are the good indicators of multiphase evolution of the margin.

Our modeling gives strong indications of the imposed tectonic boundary condition for the active deformation of RSCM. Modeling result shows during the phase of uplift, stretching and fracturing occurs in the brittle crust and results in the concentration of the tensional stress field and deformation along the margin. Noticeably tensional stress field is higher during uplift than the extension phase in our modeling. This can be

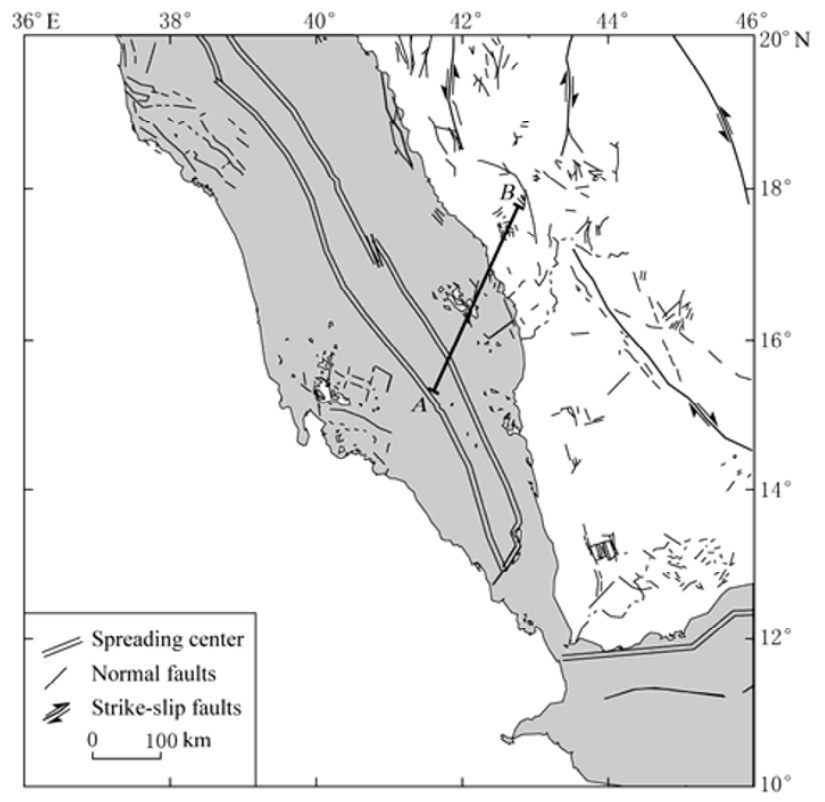

Figure 14 Map of active faults of the studied area (modified from http://discoverourearth.org/webmap/). $A B$ is a line of cross section.

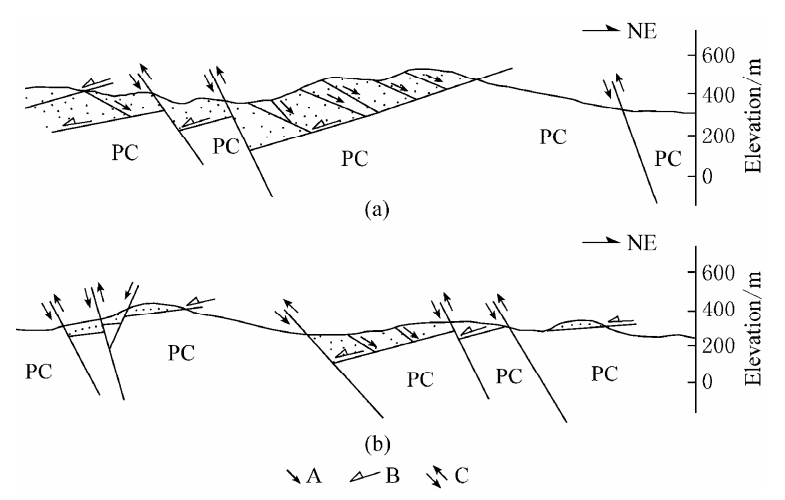

Figure 15 (a) Geological sketch map of Wajid sandstone ridges of the RSCM; (b) Schematic profile. A, B, and C denote older normal faults (fault set I, Figure 2), low-angle antithetic normal faults (not shown in Figure 2), and major synthetic normal faults (fault set II, Figure 2), respectively. PC is Precambrian. No vertical exaggeration (modified after Bohannon, 1986). See Figure 1 for location.

explained by excess gravitational potential energy attained by the crust during uplift and then collapse following extension and brittle faulting to form extensional features along the margin (e.g., Bott, 1976). Localization of tensional failures is equivalent to normal faults. We have obtained shallow depth-related deformation that is common in the extensional environment. As confirmed by field observations, most of the faults are obtained within shallow depth range (Bohannon, 1986; Pallister, 1987; Voggenreiter et al, 1988; Bohannon et al, 1989; 
Pedone et al, 1992) (Figure 15). Seismicity studies, on the other hand, also show that Red Sea is an area of occurring frequent earthquakes shallower than $18 \mathrm{~km}$ to 10 km (Figure 13) (Merghelani and Gallanthine, 1980; Makris and Rhim, 1991; Al-Amri, 1994; Sen and Al-Suba'i, 2001). Likewise, focal mechanism solutions show majority of large earthquakes in the Red Sea are originated from shallow crustal depths that are mostly characterized by normal faulting, with some strike-slip components (Merghelani and Gallanthine, 1980; Huang and Solomon, 1987). These results show very good consistency with the modeling results as well as observed deformation. At initial stage of extension modeling results confirm concentration of failure elements in the upper crust near RSCM, which during later stages propagates downward toward lower crust. Such type of fault propagation is typical in intra-plate rifts (Carminati et al, 2004) and can be explained as combined effect of variation of crustal thickness and crustal strength. In addition, shear stresses are localized along the margin, which represent accumulation of elastic stress and strain during the evolution of faults. These elastic stresses can be regarded as active source of earthquakes which, after obtaining critical value, are likely to be reactivated in future.

In overall, the occurrence of high number of failure elements, prevalent stress field, strain and shear stresses confirm that RSCM is characterized by intense deformation, and seismicity related to mantle upwelling and extending lithosphere. Due to the intense deformation, most probably, low strength rocks occur along the margin. Our results demonstrate that uplift had been involved in more effective deformation of the margin than extension itself. This supports the idea that mantle plume, under the continental heating, weakened the overlying crust and caused crust to expand and fracture due to regional stress and developed the margin. Understanding the impact of such regional tectonics on stress distribution, faulting and deformation structures have profound implications for the hydrocarbon reservoirs and seismic vulnerability along the RSCM.

\subsection{Model set-up and limitations}

In this study, we have modeled southeastern RSCM by considering extension and uplift as a boundary condition for particular tectonic events. Since the purpose was to simulate how continental margin will respond at these tectonic events, our models do not present continuous models. We interpret our modeling results simply in terms of stress field and failure elements for the particular event of extension and uplift. Elastic rheology is assumed for the modeling with the intention that faults can be modeled, however, in nature it could be elastoplastic. Each rock layer is considered homogeneous, isotropic with regular geometry. However, in nature the behavior of rock layers are not homogeneous and isotropic. We performed series of calculations to determine the appropriate values of rock parameters and the most suitable set was adopted for the modeling. Displacement has been applied instead of the stress or force, since the relative velocity of African and Arabian plates is well constrained. Elastic deformation is observed until stresses reach the Mohr-Coulomb failure envelope, after which sliding occurs on discrete faults, a condition that should be strictly applied to brittle crustal rocks.

\section{Conclusions}

The application of FE modeling enabled our understanding in the structural development of the Red Sea and its continental margin. Modeling results have demonstrated that the displacement boundary conditions and physical property of rock layer control the active deformation of the region. Stress state is dominated by both compressive and tensional stress during extension and uplift events. These events are responsible to produce an extended zone, surface structures, normal faults and active deformation of the margin. Important extensional faulting began after the eruption of volcanic rocks and has produced highlands. Modeled stress field, failure elements and shear stress suggest that mantle plume, under the continental heating, strained and weakened the overlying crust and caused crust to expand and fracture due to regional stress and developed the margin. These results are consistent with the interpretation of present seismicity, active faults and neotectonic studies.

Acknowledgements Sunil Kumar Dwivedi is grateful to the Japanese Government Ministry of Education and Sports for the Monbukagakusho scholarship. The authors are thankful to anonymous reviewers for the critical comments and suggestions.

\section{References}

Al-Amri A (1994). Seismicity of the south-western Arabian Shield and southern Red Sea. J Afr Earth Sci 19: 17-25.

Alsharhan A S and Nairn A E M (1997). Sedimentary Basins and Petroleum Geology of the Middle East. Elsevier, Amsterdam, 843.

Alsharhan A S and Salah M G (1995). Geology and hydrocarbon habitat in rift setting: Northern and central Gulf of Suez, Egypt. Bull Can Petr Geol, 43(2): 156-176.

Ambraseys N and Melville C P (1983). Seismicity of Yemen. Nature 303: 321-323. 
Ambraseys N, Melville R and Adams R (1994). Seismicity of Egypt, Arabia and the Red Sea: A Historical Review. Cambridge University Press, London, 181 .

Anderson E M (1951). The Dynamics of Faulting. 2nd ed. Oliver \& Boyd, Edinburgh, 208

Barazangi M (1981). Elevation of seismic risk along the western part of the Arabian plate: Discussion and recommendations. Bull Earth Sci 4: 77-87.

Bohannon R G (1986). Tectonic configuration of the western Arabian continental margin, Southern Red Sea. Tectonics 5: 477-499.

Bohannon R G and Eittreim S L (1991). Tectonic development of passive continental margins of the southern and central Red Sea comparison to Wilkes Land, Antarctica. Tectonophysics 198: 129-154.

Bohannon R G, Naeser C W, Schmidt D G and Zimmwermann R G (1989). The timing of uplift, volcanism and rifting peripheral to the Red Sea: A case for passive rifting? J Geophys Res 94: 1 683-1 701.

Bonatti E (1985). Punctiform initiation of seafloor spreading in the Red Sea during transition from a continental to an oceanic rift. Nature 316: 33-37.

Bonatti E and Seyler M (1987). Crustal underplating and evolution in the Red Sea rift: Uplifted Gabbro/Gneiss crustal complexes on Zabargad and Brothers Islands. J Geophys Res 92: 12 803-12 821.

Bosworth W (1987). Off-axis volcanism in the Gregory rift, east Africa: Implications for models of continental rifting. Geology 15: 397-400.

Bosworth W and Strecker M R (1997). Stress field changes in the Afro-Arabian rift system during the Miocene to Recent period. Tectonophysics 278: 47-62.

Bott M H P (1976). Formation of sedimentary basins of graben type by extension of the continental crust. Tectonophysics 36(1-3): 77-86.

Carminati E, Doglioni C and Barba S (2004). Reverse migration of seismicity on thrusts and normal faults. Earth Sci Rev 65: 195-222.

Chu D and Gordon R G (1998). Current plate motions across the Red Sea. Geophys J Int 135: 313-328.

Clark S P Jr (1966). Handbook of Physical Constants. Geological Society of America Memoir 97, New York, 587.

Davison I, Al-Kadasi M, Al-Khirbash S, Al-Subbary A, Baker J, Blakey S, Bosence D, Dart C, Heaton R, McClay K, Menzies M, Nichols G, Owen L and Yelland A (1994). Structural evolution of the southeastern Red Sea margin, Republic of Yemen. Geol Soc Amer Bull 106: 1 474-1 493.

Dwivedi S K and Hayashi D (2006). Neotectonic stress analysis of the Red Sea rift by finite element modeling. Eos, Trans Amer Geophys Union 87: Abstract, T31D-0479.

Dwivedi S K and Hayashi D (2007). Neotectonic stress analysis of the Red Sea rift by finite element modeling. Bull Fac Sci Univ Ryukyus 83: 3-28.

Dwivedi S K and Hayashi D (2008). FE modeling of contemporary stress field in northeast Africa: Implications for the kinematics of Suez rift. Boll Geofis Teor Appl 49(Suppl. 2): 318-323.

Finkbeiner T, Zoback M, Flemings P and Stump B (2001). Stress, pore pressure, and dynamically constrained hydrocarbon columns in the south Eugene Island 330 Field, Northern Gulf of Mexico. AAPG Bulletin 85: $1007-1031$.

Ghebreab W (1998). Tectonics of the Red Sea region reassessed. Earth Sci Rev 45: $1-44$.

Giraud A, Trouvenot F and Huber R (1986). Tectonic stress in the southwestern Saudi Arabia. Eng Geol 22: 247-255.

Girdler R W (1985). Problems concerning the evolution of oceanic lithosphere in the northern Red Sea. Tectonophysics 116: 109-122.

Girdler R W (1991). The Afro-Arabian Rift System - an overview. Tectonophysics 197: 139-153.

Girdler M E and Underwood M (1985). The evolution of early oceanic lithosphere in the northern Red Sea. Tectonophysics 116: 95-108.

Guiraud R and Bosworth W (1997). Senonian basin inversion and rejuvenation of rifting in Africa and Arabia: synthesis and implications to plate-scale tectonics. Tectonophysics 282: 39-82.

Guiraud R and Bosworth W (1999). Phanerozoic geodynamic evolution of northeastern Africa and the northwestern Arabian platform. Tectonophysics 315: 73-108.

Hayashi D (2008). Theoretical basis of FE simulation software package. Bull Fac Sci Univ Ryukyus 85: 81-95, http://ir.lib.u-ryukyu.ac.jp.
Hempton M R (1987). Constraints on Arabian plate motion and extensional history of the Red Sea. Tectonics 6: 687-705.

Huang P Y and Solomon S C (1987). Centroid depths and mechanisms of mid-oceanic ridge earthquakes in the Indian Ocean, Gulf of Aden and Red Sea. J Geophys Res 92: 1 361-1 383.

Joffe S and Garfunkel Z (1987). Plate kinematics of the circum Red Sea - a re-evaluation. Tectonophysics 141: 5-22.

Johnson P R (1998). Tectonic map of Saudi Arabia and adjacent areas. In: Saudi Arabian Deputy Ministry for Mineral Resources Technical Report USGS-TR-98-3, 1:40 $000000,2$.

Kaliwoda M, Altherr R and Meyer H P (2007). Composition and thermal evolution of the lithospheric mantle beneath the Harrat Uwayrid, eastern flank of the Red Sea rift (Saudi Arabia). Lithos 99: 105-120.

Konert G, Afifi A M, Al-Hajri S A and Droste H J (2001). Paleozoic stratigraphy and hydrocarbon habitat of the Arabian Plate. GeoArabia 6(3): 407-441.

Makris M J and Rhim R (1991). Shear-controlled evolution of the Red Sea: pull-apart model. Tectonophysics 198: 441-466.

McClusky S, Reilinger R, Mahmoud S, Ben Sari D and Tealeb A (2003). GPS constraints of Africa (Nubia) and Arabia plate motions. Geophys J Int 155 $126-138$.

McKenzie D (1978). Some remarks on the development of sedimentary basins. Earth Planet Sci Lett 40: 25-32.

Melosh H J and Williams C A Jr (1989). Mechanics of graben formation in crustal rocks: A finite element analysis. J Geophys Res 94: 13 961-13973.

Merghelani H and Gallanthine S (1980). Microearthquakes in the Tihamat-Asir region of Saudi Arabia. Bull Seism Soc Amer 70: 2 291-2 293.

Mooney W D, Gettings M E, Blank H R and Healy J H (1985). Saudi Arabian seismic refraction profile: a traveltime interpretation of crustal and upper mantle structure. Tectonophysics 111: 173-246.

Pallister J S (1987). Magmatic history of Red Sea rifting: Perspective from the central Saudi Arabian coastal plain. Bull Geol Soc Amer 98: 400-417.

Pedone R, Lombardo P and Diamantidis D (1992). Seismotectonic regionalization of the Red Sea area and its application to seismic Risk analysis. Nat Hazards 5: 233-247.

Reches Z and Schubert G. 1987. Models of post Miocene deformation of the Arabian plate. Tectonics 6: 707-725.

Reilinger R E, McClusky S C, Souter B J, Hamburger M W, Prilepin M T, Mishin A, Guseva T and Balassanian S (1997). Preliminary estimates of plate convergence in the Caucasus collision zone from global positioning system measurements. Geophys Res Lett 24: 1 815-1 818.

Sen Z and Al-Suba'i K (2001). Seismic hazard assessment in the Tihamat Asir region, southwestern Saudi Arabia. Mathematical Geol 33: 967-991.

Sengör A M C and Burke K (1978). Relative timing of rifting and volcanism on Earth and its tectonic implications. Geophys Res Lett 5: 419-421.

Strecker M R and Bosworth W (1991). Quaternary stress-field change and rifting processes in the East African Gregory Rift. Eos, Trans Amer Geophys Union 72: 17-22.

Strecker M R, Blisniuk P M and Eisbacher G H (1990). Rotation of extension direction in the central Kenya Rift. Geology 18: 299-302.

Timosenko S P and Goodier J N (1970). Theory of Elasticity. 3rd ed. McGraw Hill Book Company, London, 567.

Turcotte D L and Emermen S H (1983). Mechanisms of active and passive rifting. Tectonophysics 94: 39-50.

Vita-Finzi C (2001). Neotectonics at the Arabian plate margins. J Structural Geol 23: 521-530.

Voggenreiter W, Hötzl H and Jado A R (1988). Red Sea related history of extension and magmatism in the Jizan area (Southwest Saudi Arabia): Indication for simple-shear during early Red Sea rifting. Geol Rundsch 77: 257-274.

Wernicke B (1985). Uniform-sense normal simple shear of the continental lithosphere. Can J Earth Sci 22: 108-125.

White R and McKenzie D (1989). Magmatism and rift zones: The generation of volcanic continental margins and flood basalts. $J$ Geophys Res 94 : $7685-7729$.

Ziegler P and Cloetingh S (2004). Dynamic processes controlling evolution of rifted basins. Earth Sci Rev 64: 1-50. 